\title{
INFLUENCES OF BIOLOGICAL PREPARATIONS ON SOIL PROPERTIES IN THE SPRING WHEAT CROP
}

Rita ČEPULIENE், Institute of Agroecosystems and Soil Science, Faculty of Agronomy, Aleksandras Stulginskis University. Studentų g. 11, Akademija LT-53361, Kauno r., Lithuania. rita.cepuliene@gmail.com (corresponding author)

Darija JODAUGIENĖ, Institute of Agroecosystems and Soil Science, Faculty of Agronomy, Aleksandras Stulginskis University. Studentų g. 11, Akademija LT-53361, Kauno r., Lithuania. darija.jodaugiene@agmail.com

The natural biochemical, biophysical and biological processes in the soil is changing due to the intensive use of pesticides. At present, it is actual fertilization technologies, which are based on non-fertilizer rates increase bat on their rational use because in the fertilizer is unnecessary chemical compounds that promote mineral nutritional elements leaching. Have been studied the effect of biological preparations BactoMix, AgroMik and Rizobakterin on soil physical properties. Experiments were carried out in 2015-2016 at the Experimental Station of Aleksandras Stulginskis University on Calcari-Endohypogleyic Luvisol. The mean annual temperature of the study site is $6.0-6.5^{\circ} \mathrm{C}$, mean annual precipitation is $600-650 \mathrm{~mm}$ and mean annual length of sun shine is $1750-1800$ hour (Lithuanian Hydrometeorological Service). Biological preparations sprayed on the soil surface and incorporated in the soil by sowing spring wheat. The use of biological preparations had a tendency to reduce soil density (from 2.3 to $5.3 \%$ ), to increase soil porosity (from 0.6 to $2.1 \%$ ). Biological preparations had no significant influence on quantity couples filled with moisture and air. The hardness of the soil after spring wheat harvest was the smallest in the fields sprayed by Rizobakterin preparation. The use of biological preparations BaktoMix and Rizobakterin significantly increased soil moisture. The following preparations significantly decreased soil pulverized fractions (micro structure) and significantly increased amount of particles larger than $10 \mathrm{~mm}$.

Keywords: biological preparations, soil physical properties

\section{INTRODUCTION}

Intensifying production of agriculture, rising prices of energy resources, and the EU ecological policy goals are forcing farmers to seek solutions to reduce labour and production costs and energy resources. At the same time, new and efficient measures are sought to increase plant fertility and improve crop quality. Mineral nutrition of plants is one of the main factors, which affects the aforementioned crop indicators. Currently there has to be an increase in relevance of fertilization technologies based not on fertilizer norm increase but on its rational use and on application of measures that influence the increase in assimilation of mineral nutrition elements because when traditional fertilization technologies are used, the portion of fertilizer that is unassimilated by plants constitutes substantial economic loss. Furthermore, mineral fertilizer not only enriches the soil with various elements that are prerequisite for plant nutrition, but also includes unnecessary chemical compounds and stimulates leaching of mineral nutrients. After entering the soil, fertilizer changes its typical cation-anion balance and enhances the migration of base cations to the wider horizons. Some anions (of sulphur, chlorine, nitrogen) form strong acids in the soil solution and thus, in combination with the aforementioned factors, increase soil acidity.

Intensive use of pesticides modifies the natural biochemical, biophysical and biological processes in the soil. Due to a lack of oxygen and humidity on soil surface, microorganisms, micro fauna and micro flora die. The decline of these microorganisms results in a weakened decomposition of organic waste, which directly depends on the species composition and quantity in the soil micro flora.

The aim of this work is to determine the possibilities of soil improvement and production increase for spring wheat agrocenoses by using biological preparations (BactoMix, AgroMik and Rizobakterin) for soil spray and to evaluate their efficiency.

\section{MATERIALS AND METHODS}

The experiment was conducted in 2015-2016 in the Experimental Station of Aleksandras Stulginskis University, in Calcari-Endohypogleyic Luvisol, a semi-neutral $\left(\mathrm{pH}_{\mathrm{KCl}} 6.8\right)$, highly phosphorous (226.6 $\mathrm{mg} \mathrm{kg}^{-1} \mathrm{P}_{2} \mathrm{O}_{5}$ ), mid-potassium-

Copyright (C) 2017 The Authors. Published by Aleksandras Stulginskis University. This is an open-access article distributed under the terms of the Creative Commons Attribution License (CC-BY 4.0), which permits unrestricted use, distribution, and reproduction in any medium, provided the original author and source are credited. 
level $\left(105.0 \mathrm{mg} \mathrm{kg}^{-1} \mathrm{~K}_{2} \mathrm{O}\right)$, mid-humus-level $(2.33 \%)$ soil, in order to evaluate the effect of biological preparations BactoMix, AgroMik and Rizobakterin on physical properties of the soil.

The experiment was was carried out in three repetitions in a spring wheat crop. Experiment variants: 1) biological preparations were not used, 2) biological preparation BactoMix was sprayed (norm $\left.11 \mathrm{ha}^{-1}\right), 3$ ) biological preparation AgroMik was sprayed (norm $\left.41 \mathrm{ha}^{-1}\right)$, 4) biological preparation Rizobakterin was sprayed (norm $21 \mathrm{ha}^{-1}$ ). Variants were arranged randomly. The size of the initial field was $240 \mathrm{~m}^{2}$, the size of accounting field was $128 \mathrm{~m}^{2}$.

The soil of the field test was harrowed in autumn. In spring, when the soil reached physical maturity, it was cultivated twice. After the second cultivation, biological preparations were sprayed on the soil surface when the ambient temperature did not exceed $18^{\circ} \mathrm{C}$ and the spring wheat was sowed at once, while simultaneously harrowing and pressing it with wheeled rollers. The spring wheat strain 'Triso' was sowed, the seed rate was $200 \mathrm{~kg} \mathrm{ha}^{-1}$, and also local fertilization with Azofoska $300 \mathrm{~kg} \mathrm{ha}^{-1}\left(\mathrm{~N}_{15} \mathrm{P}_{15} \mathrm{~K}_{15}\right)$ was used. The wheat was sowed with the pneumatic seeding machine HORSCH $\mathrm{CO}$ 6. During the tillering period, spring wheat was additionally fertilized with ammonium nitrate $200 \mathrm{~kg} \mathrm{ha}^{-1}$. Spring wheat was sprayed against weeds with the herbicide Mustang $1.21 \mathrm{ha}^{-1}$ and against diseases with the fungicide Bumper 25 EC $0.51 \mathrm{ha}^{-1}$. The wheat was harvested using small size combine harvester Wintersteiger Delta with weighing and humidity detection system.

The agrophysical features of the soil (density, humidity, porosity, amount of pores filled with air and water, soil penetration resistance and soil structure) were determined at the outset of the experiment preparation (spring): during the tillering period of spring wheat and after the harvest, in the $0-15 \mathrm{~cm}$ soil layer in four field locations. Soil penetration resistance was measured using an electronic hardness-meter in the $0-20 \mathrm{~cm}$ soil layer in five field locations in the beginning of the spring wheat tillering period and after the harvest.

Research data was evaluated with the method of analysis of variance, using the computer software ANOVA from the software pack SYSTAT 10 (SPSS, 2001).

\section{RESULTS AND DISCUSSION}

Soil density is one of the main physical features dependant on the soil's mineral composition, porosity, structure, humus content etc. Most scientists claim that soil density and porosity have a direct influence on soil microclimate and microorganism activity (Gomez et al.; 1999; Rasmussen, 1999; Kay and VandenBygaart, 2002). In a hard soil, plant nutrition is disrupted, because the roots do not receive enough oxygen and develop more weakly, the plants have trouble overwintering because such soil freezes more quickly and more deeply. In a porous soil, there is more oxygen and it withholds cold (Hacke et al., 2000). Earthwork has a great influence on soil density. As the soil density changes, the humidity and heat regime also changes in the soil, as well as biological activity, plant root distribution and volume in addition to the plant crop (Jones, 1983; Shaffer, 1998; Sakin et al., 2011; Chaudhari et al., 2013).

The utilised biological preparations did not have a fundamental influence on soil density, but a trend of soil density decrease could be identified in the fields that were sprayed with biological preparations (Fig. 1).

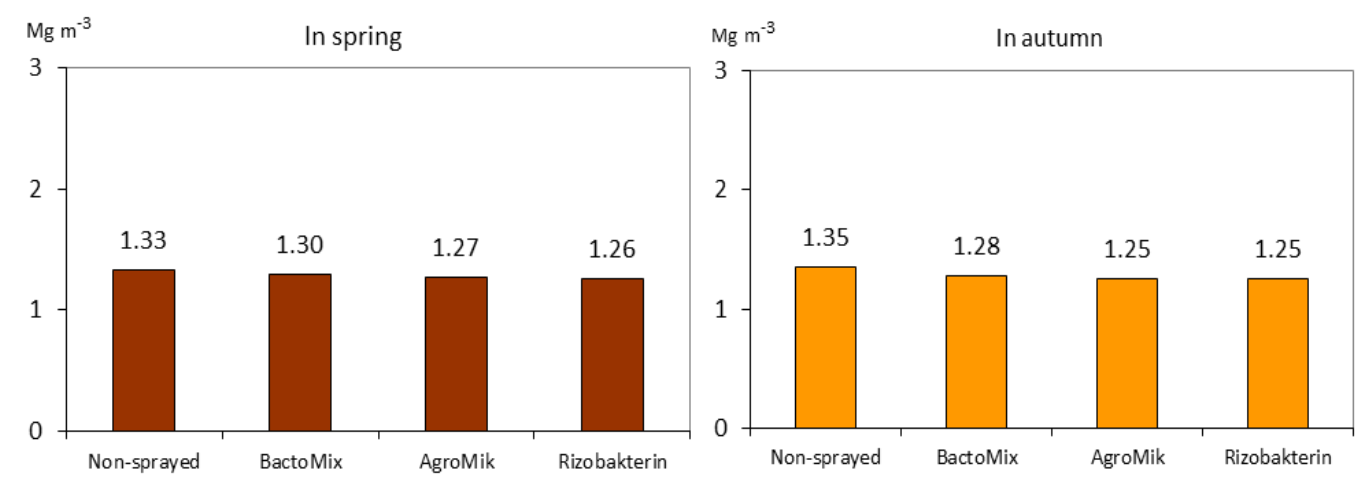

Note: statistically insignificant differences

Figure 1. Influence of biological preparations on soil density in the spring wheat crop

In spring soil density fluctuated between 1.26 and $1.33 \mathrm{Mg} \mathrm{m}^{-3}$. In the fields where biological preparations were sprayed the soil density was detected to be $2.3-5.3 \%$ lower than in the unsprayed fields. The same trend was identified in autumn as well, after harvesting the spring wheat. In the fields sprayed with biological preparations, the soil density was 5.2-7.4\% lower compared to the soil density in fields that were not sprayed with biological preparations. However, no fundamental differences were identified.

Most agricultural plants are sensitive to cultivation conditions, which are particularly influenced by soil humidity. Soil layer humidity in moderate soil that is optimal for wheat is 17-18 \% (Feiza and Arlauskas, 1995). According to other opinions, the optimal soil humidity in moderate clayey soil is $19-23 \%$ (conditions of excessive humidity >29\%, wet 24-28 \%, close to optimal 13-18\%, dry - 7-12\%, very dry - <7\%) (Mazvila et al., 2008).

Soil humidity in spring during the tilling period of spring wheat did not differ substantially, however, it was a bit higher (0.4-1.6 percent per unit) in the fields sprayed with biological preparations than in those that were not sprayed (Fig. 2). 

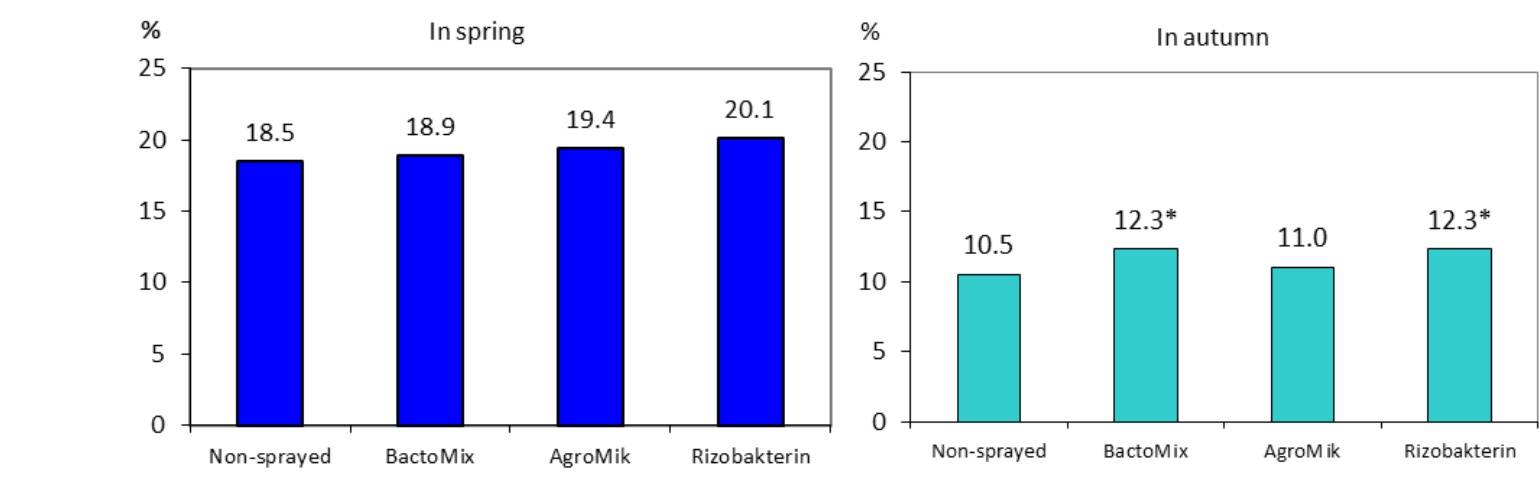

Note $*$ - statistically significant $\mathrm{P}<0.05$

Figure 2. Influence of biological preparations on soil humidity in the spring wheat crop

Following the harvest of the spring wheat, when very dry weather dominated, the soil humidity was detected to be higher by $0.5-1.8$ percent per unit in the fields that were sprayed with biological preparations. Fundamentally higher soil humidity was identified in the fields sprayed with BaktoMix and Rizobakterin biological preparations.

According to the data of various authors the optimal soil density in the clayey soils for the winter grains is $1.2-1.4 \mathrm{Mg} \mathrm{m}^{-3}$, which corresponds to $53.8-46.2 \%$ general porosity; for the summer grains and rape, it is $1.2-1.3 \mathrm{Mg} \mathrm{m}^{-}$ 3 , which corresponds to $53.8-50.0 \%$; and for potatoes and beetroots, it is $1.0-1.3 \mathrm{Mg} \mathrm{m}^{-3}$, which corresponds to $61.5-$ $50.0 \%$ general porosity (Mazvila et al., 2008). The permissible critical general porosity for agricultural plants is $41-$ $47 \%$. The most favourable plant growth conditions are when the pores filled with humidity and air amount to $50 \%$ each (Zimkuviene and Kedziuviene, 1989).

After calculating the general porosity of the soil, it was determined that it was optimal or close to optimal throughout the entire research period. In the interval of spring wheat tilling, the soil porosity fluctuated between $49.4 \%$ in the non-sprayed fields and 50.0-51.5 in the fields sprayed with biological preparations (Fig. 3).
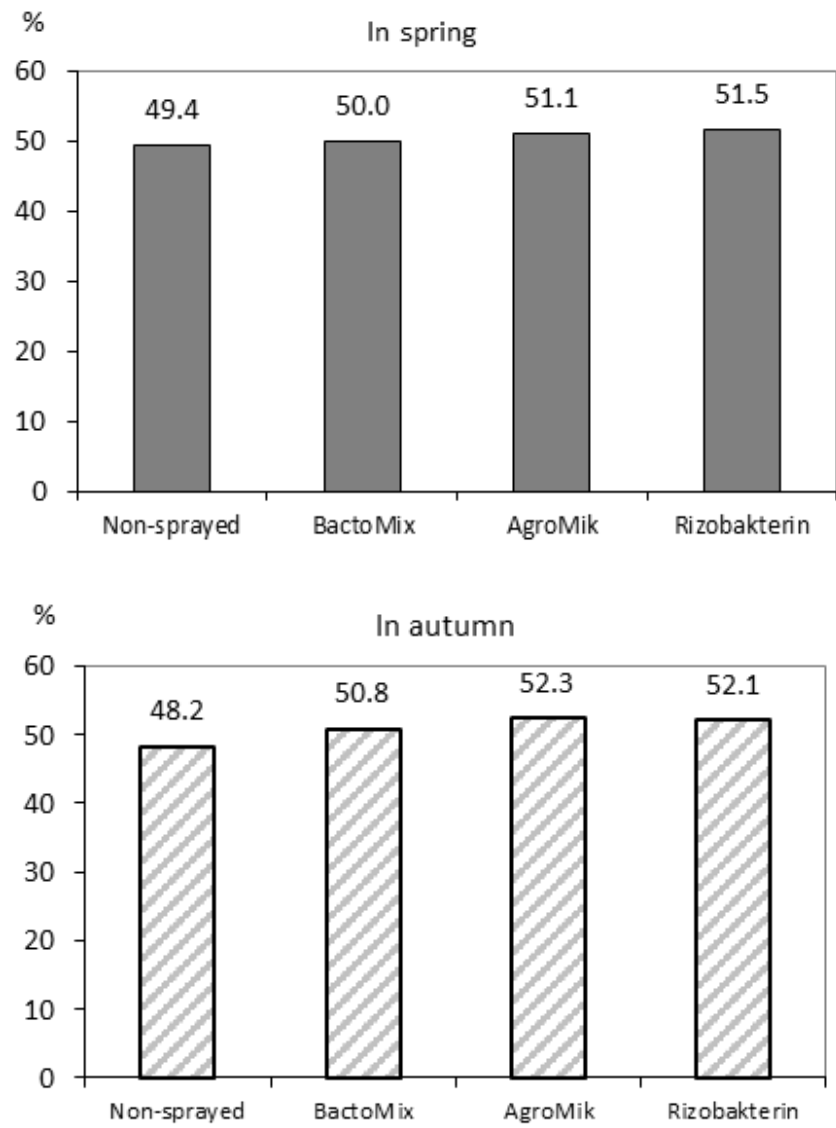

Note: statistically insignificant differences

Figure 3. Impact of biological preparations on soil porosity in the spring wheat crop

After the harvest of the spring wheat, higher soil porosity was detected in the fields sprayed with biological preparations, but no fundamental differences were identified. 
Soil penetration resistance is expressed as the force necessary to press a solid body of the corresponding diameter into the soil. The penetration resistance mostly depends on soil density, granulometric composition and humidity. As soil density increases and the humidity decreases, the penetration resistance rises. As the amount of humus and humidity grows in the soil, the penetration resistance declines. It has been observed that in spring, as soon as dry weather becomes predominant, the plants suffer from stress more quickly in the soils where the penetration resistance exceeds the optimal limits. After determining that a soil is hard, we can state that the porosity of such soil is reduced and its water cycle is disturbed (López Bravo et al., 2016). Increased soil penetration resistance has both positive and negative impact. The positive impact is that the soil's resistance against pressure is boosted, and the negative impact is that energy expenditure on land cultivation is increased. Soil penetration resistance changes during plant vegetation. Soil penetration resistance was uneven during the spring wheat tillering period (Fig. 4 a).

On the surface of the soil (up to $3 \mathrm{~cm}$ ), it did not change substantially, but in the deeper layers it was lower in the fields that were sprayed with BactoMix and Rizobakterin biological preparations. AgroMik preparation did not have a great influence on soil penetration resistance. Penetration resistance in the fields sprayed by this preparation was similar to that of the unsprayed fields. In the $15-20 \mathrm{~cm}$ layer of the soil, penetration resistance was similar in all fields. Soil penetration resistance after the reaping of spring wheat crop was the lowest in the fields sprayed with Rizobakterin preparation (Fig. 4 b). In the fields sprayed with the biological preparation AgroMik, soil penetration resistance remained the same as during the spring wheat tillering period, in spite of the very dry soil. However, it can be noted that the impact of BactoMix preparation disappeared before the harvest of the wheat and penetration resistance was similar to that of the unsprayed fields.

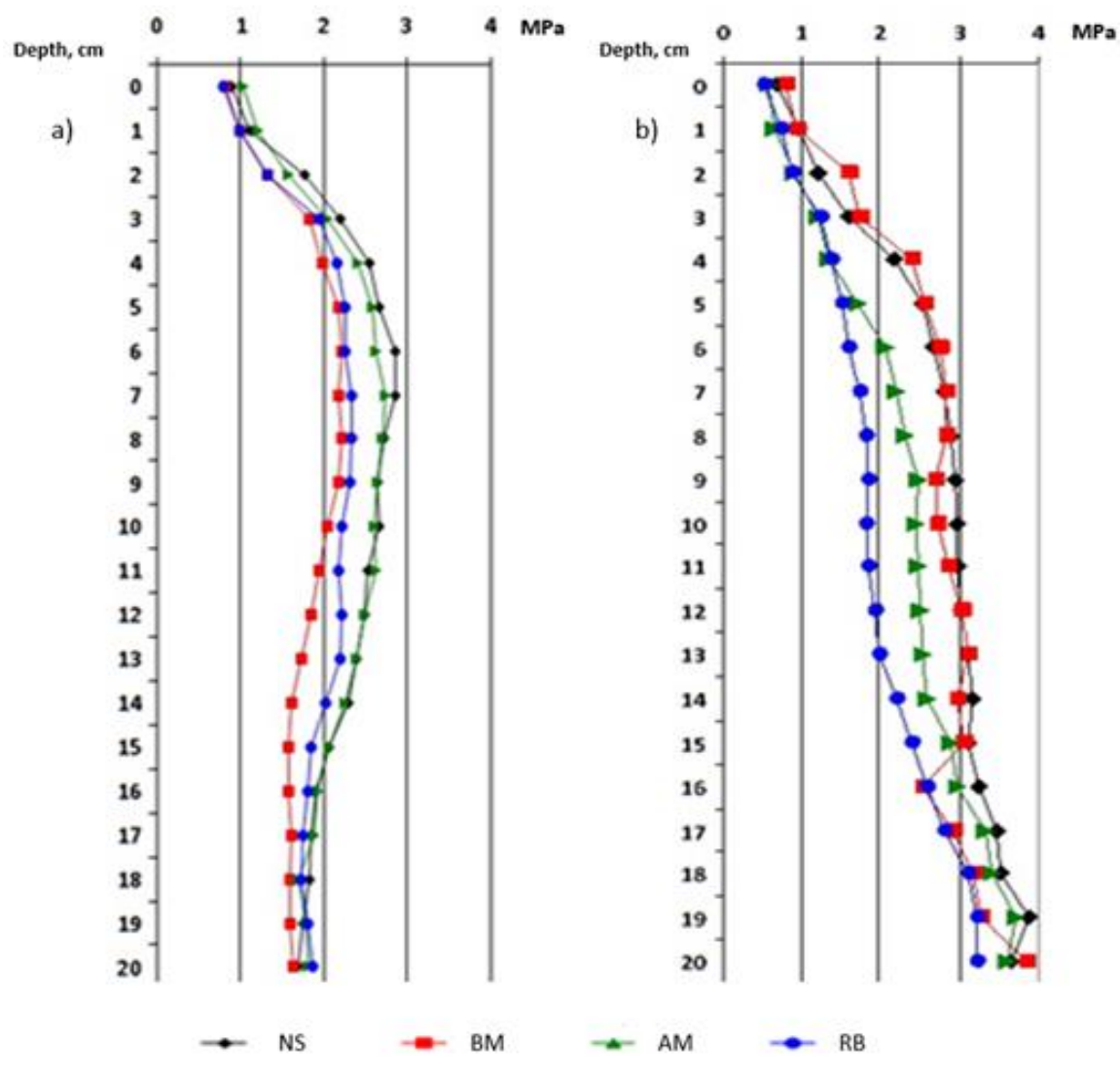

(NS - non-sprayed, BM - BactoMix, AM - AgroMik, RB - Rizobacterin)

Figure 4. Impact of biological preparations on soil penetration resistance in the spring wheat crop a) in the tillering period; b) after the harvest

The structure is characterised by soil aggregates whose diameter varies between 0.1 and $10 \mathrm{~mm}$. The most valuable agronomically are the $0.25-5 \mathrm{~mm}$ sized aggregates. The soils that contain $40-60 \%$ of water-enduring aggregates $(>0.25 \mathrm{~mm})$ are the most suitable for land cultivation (Dexter, 1988). Soil structure in the fields was uneven after the presowing cultivation and before the spraying of biological preparations (Fig. 5) 

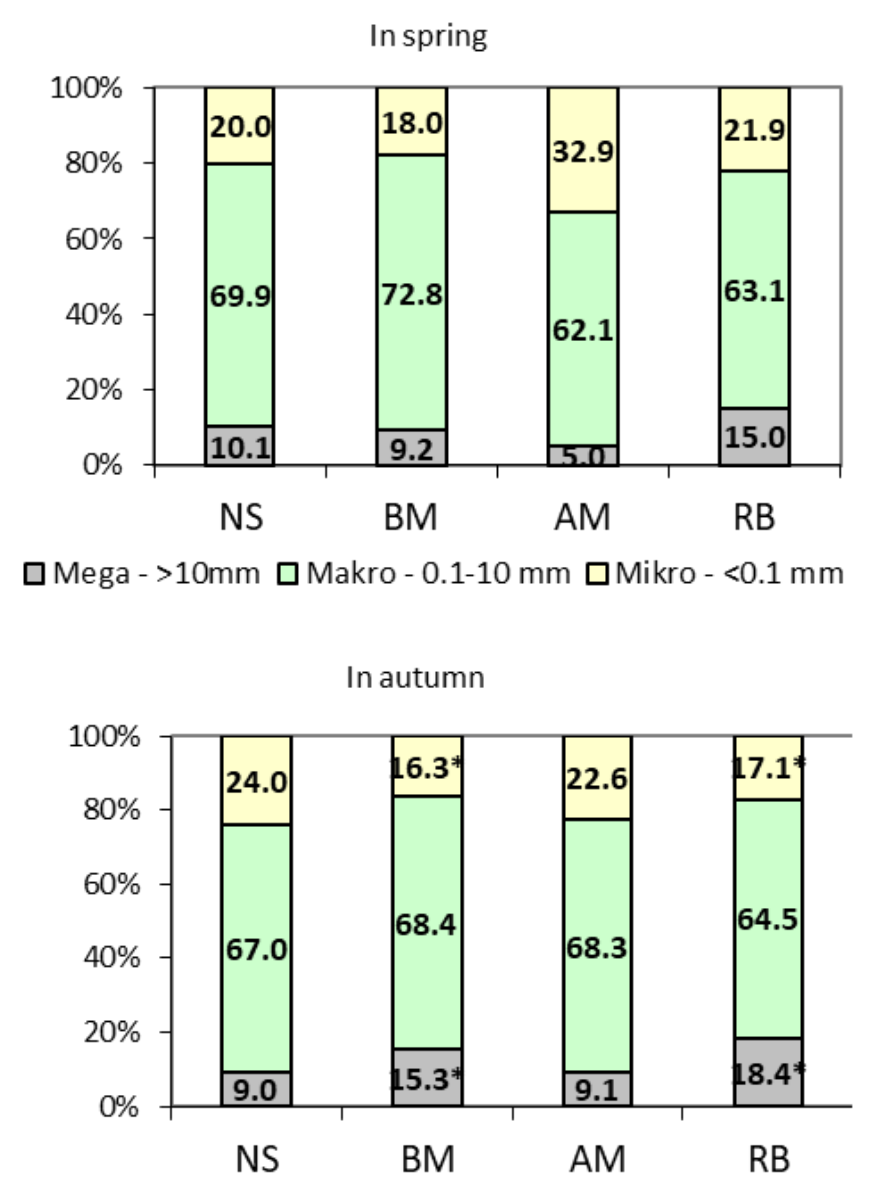

Note *- statistically significant $\mathrm{P}<0.05$

NS - non-sprayed, BM - BactoMix, AM - AgroMik, RB - Rizobacterin

Figure 5. Soil structure before the spraying of biological preparations in spring and after the spring wheat harvest

The amount of soil clumps whose diameter is over $10 \mathrm{~mm}$ (megastructures) was between 5 and $15 \%$, i.e. their quantity varied by up to 3 times. The fluctuations of the macrostructures, the soil clumps whose diameter is $0.1-10 \mathrm{~mm}$, were lower. Their amount varied from 62.1 to $72.8 \%$.

The largest amount of dust fractions (microstructures) or particles smaller than $0.1 \mathrm{~mm}$ was found in the fields that were later sprayed with AgroMik biological preparation. However, it should be noted that due to large data variation, no fundamental differences were identified.

Soil structure after the spring wheat harvest was different in the fields that were sprayed with biological preparations and in those that were not. One particular standout was the soil of the fields that were sprayed with BactoMix and Rizobakterin preparations. The amount of macrostructures or the soil particles sized $0.1-10 \mathrm{~mm}$ in diameter was similar in all fields. Their number varied between 64.5 and $68.4 \%$ and did not differentiate highly. However, it can be noted that the soil of fields sprayed with BactoMix and Rizobakterin preparations had fundamentally reduced amount of dust fractions (microstructures) and fundamentally increased amount of particles whose diameter is larger than $10 \mathrm{~mm}$. Bronick and Lal (2005) notice that the use of biological biopreparations is possible to recover soils by activating microbiological processes and in symbiosis with plants, microorganisms fulfil many functions.

\section{CONCLUSIONS}

Research results have shown that biological preparations had a tendency to reduce soil density and increase soil humidity and porosity.

Soil penetration resistance during the tillering period of the spring wheat was lower in the fields sprayed with BactoMix and Rizobakterin biological preparations. Before the harvesting of spring wheat, soil penetration resistance remained lower in the fields sprayed with AgroMik and Rizobakterin preparations.

Biological preparations affected the soil structure. In the fields sprayed with BactoMix and Rizobakterin, there was a fundamental decrease of dust fractions (microstructures) but also a fundamental increase in the quantity of particles larger than $10 \mathrm{~mm}$. Biological preparations in combination with fertilizer and plant protection measures may cause a fundamental shift in the farming philosophy. 


\section{REFERENCES}

1. Bronick, C.J., Lal, R. 2005. Soil structure and management: a review. Geoderma. Vol. 124, pp.3-22. https://doi.org/10.1016/j.geoderma.2004.03.005

2. Chaudhari, P.R., Ahire, D.V., Ahire, V.D., Chkravart, M., Maity, S. 2013. Soil Bulk Density as related to Soil Texture, Organic Matter Content and available total Nutrients of Coimbatore Soil. International Journal of Scientific and Research Publications. Vol.3, Iss. 2, pp.1-8.

3. Dexter, A.R. 1988. Advances in characterization of soil structure. Soil and Tillage Research. Vol. 11, pp.199-238. https://doi.org/10.1016/0167-1987(88)90002-5

4. Feiza, V.; Arlauskas, M. 1995. Methods of primary soil cultivation on sloping agricultural land in Western Lithuania. Zemes ukio mokslai, Vol. 4, pp.14-17.

5. Gomez, J.A., Giraldez, J.V., Pastor, M., Fereres, E. 1999. Effects of tillage method on soil physical properties infiltration, and yield in an olive orchard. Soil and Tillage Research. Vol. 52, pp.167-175. https://doi.org/10.1016/S0167-1987(99)00078-1

6. Hacke, U.G., Sperry, J.S., Ewers, B.E., Ellsworth, D.S., Schafer, K.V.R., Oren, R. 2000. Influence of soil porosity on water use in Pinus taeda. Oecologia, Vol. 124, pp.495-505. https://doi.org/10.1007/PL00008875

7. Jones, C. A. 1983. Effect of Soil Texture on Critical Bulk Densities for Root Growth. Soil Science Society American Journal. Vol. 47, pp.1208-1211. https://doi.org/10.2136/sssaj1983.03615995004700060029x

8. Kay, B. D.; Vanden Bygaart, A. J. 2002. Conservation tillage and depth stratification of porosity and soil organic matter. Soil and Tillage Research. Vol. 66, pp.107-118. https://doi.org/10.1016/S0167-1987(02)00019-3

9. Kouwenhovena, J.K., Perdoka, U.D., Boera, J., Oomen, G.J.M. 2002. Soil management by shallow mouldboard ploughing in the Netherlands. Soil and Tillage Research, Vol. 65, pp.125-139. https://doi.org/10.1016/S0167-1987(01)00271-9

10. López Bravo, E., Herrera Suárez, M., González Cueto, O., Iglesias Coronel, C., Ramon, H. 2016. Effect of Moisture and Soil Compaction on Tillage Operations. Revista Ciencias Técnicas Agropecuarias. Vol. 25, Iss. 1, pp.32-37.

11. Mazvila, J.; Staugaitis, G.; Adomaitis, T.; Arbaciauskas, J.; Vaisvila, Z.; Sumskis, D. 2008. Agrochemical properties of Lithuanian soils and their changes after regaining independence, Zemes ukio mokslai, Vol. 15, No. 3, pp.13-21.

12. Rasmussen, K. J. 1999. Impact of ploughless soil tillage on yield and soil quality: a Scandinavian review. Soil and Tillage Research. Vol. 53, pp.3-14. https://doi.org/10.1016/S0167-1987(99)00072-0

13. Sakin, E., Deliboran, A., Tutar, E. 2011. Bulk density of Harran plain soils in relation to other soil properties. African Journal of Agricultural Research. Vol. 6, Iss. 7, pp.1750-1757.

14. Shaffer, M. J. 1998. Estimating Confidence Bands for Soil - Crop Simulation Models. Soil Science Society American. Journal. Vol. 52, pp.1782-1789. https://doi.org/10.2136/sssaj1988.03615995005200060048x

15. SPSS Instant 10. I. USA. 2000. 663.

16. Zimkuviene, A.; Kedziuviene, G. 1989. Some properties of compressed soils. Soil compression and yield. Vilnius: Science, p. 10 [in Lithuanian] 